\title{
STUDY OF PREVALENCE AND RISK FACTORS OF PERIPHERAL DIABETIC NEUROPATHY IN A TERTIARY HOSPITAL
}

\author{
Onkar Nath Rai ${ }^{1}$, Vipin Mishra², Rakesh Chandra ${ }^{3}$, S. K. Saxena ${ }^{4}$, B. D. Mangal ${ }^{5}$
}

${ }_{1}^{1}$ Associate Professor, Department of Medicine, GMC, Azamgarh.

${ }^{2}$ Ex-Professor, Department of Medicine, KPS PG Institute of Medicine, GSVM Medical College, Kanpur.

${ }^{3}$ Ex-Professor, Department of Medicine, KPS PG Institute of Medicine, GSVM Medical College, Kanpur.

${ }^{4}$ Ex-Professor, Department of Medicine, KPS PG Institute of Medicine, GSVM Medical College, Kanpur.

${ }^{5}$ Ex-Professor, Department of Medicine, KPS PG Institute of Medicine, GSVM Medical College, Kanpur.

\section{ABSTRACT}

The prevalence of neuropathy in the diabetic population has been estimated ranging from $10 \%$ to $90 \%$. Generally, the incidence of neuropathy seems to increase with duration of disease. This study was undertaken to find the prevalence of peripheral neur opathy in diabetes mellitus type-2 patients and to study the effect of parameters like age, duration of disease, blood pressure and body mass index in such patients.

\section{MATERIAL AND METHODS}

This one year study was conducted among patients of Diabetes Mellitus type-2 of GSVM Medical College, Kanpur. The patients were selected via random sampling and were interviewed using a structured proforma after taking informed consent. Diagnosis of peripheral neuropathy was made on the basis of history, clinical examination, vibration perception with the help of biothesiometer Statistical multi-regression analysis was done.

\section{RESULTS}

Majority of patients belonged to 60-74 years (49.01\%) age group. Female/Male ratio in our study was 1.08:1. Prevalence of diabetic neuropathy was $60.7 \%$. A significant correlation with age of onset and duration of diabetes was found among individuals having diabetes peripheral neuropathy.

\section{CONCLUSION}

Prevalence of diabetic neuropathy in this North Indian study was high (60.7\%). A significant correlation with age and duration of disease was found. Early detection and treatment can be useful in preventing the progression of neuropathy among diabetics.

\section{KEYWORDS}

Peripheral Neuropathy, Type-2 Diabetes Mellitus.

HOW TO CITE THIS ARTICLE: Rai ON, Mishra V, Chandra R, et al. Study of prevalence and risk factors of peripheral diabetic neuropathy in a tertiary hospital. J. Evolution Med. Dent. Sci. 2016;5(13):557-559, DOI: 10.14260/jemds/2016/127

\section{INTRODUCTION}

Diabetic Peripheral Neuropathy (DPN) is a well-known microvascular complication of type 2 diabetes mellitus attributed to chronic hyperglycemia and is defined as the presence of peripheral nerve dysfunction in diabetics after exclusion of other causes. ${ }^{1-4}$ it can take many forms. They range from the "classic" chronic progressive distal symmetric neuropathies to acute mononeuropathies to pressure palsies most often affecting the median and ulnar nerves. Distal symmetric neuropathy is the most common symptomatic neuropathy associated with diabetes mellitus.

About $60 \%$ to $70 \%$ of all people with diabetes eventually develop peripheral neuropathy, but not all suffer pain. Yet this nerve damage is not inevitable. People with diabetes can reduce their risk of developing nerve damage by keeping their blood sugar levels as close to normal as possible. ${ }^{5}$

Generally, the incidence of neuropathy seems to increase with duration of disease and severity of hyperglycemia.

Financial or Other, Competing Interest: None.

Submission 27-12-2015, Peer Review 21-01-2016,

Acceptance 29-01-2016, Published 13-02-2016.

Corresponding Author:

Dr. Onkar Nath Rai,

Park Hospital, Hanuman Mandir Road,

Betiahata, Gorakhpur, Uttar Pradesh.

E-mail: onkarnathrai763@gmail.com

DOI: $10.14260 /$ jemds/2016/127
Many studies have shown a correlation between DPN and height, age and duration of diabetes worldwide, but studies from North India are scarce. With this background this study was undertaken to find the prevalence of peripheral neuropathy in diabetes mellitus type- 2 patients and to study the effect of physical parameters like age, duration of disease, blood pressure, body mass index and waist hip ratio in diabetes with peripheral neuropathy.

\section{MATERIAL AND METHODS STUDY DESIGN}

This one year study was conducted among patients of Diabetes Mellitus type-2 attending O.P. D. emergency and indoor wards of KPSIPGM and L. L. R. and Associated Hospital, GSVM Medical College Kanpur after obtaining permission from Institutional Ethical Committee. The patients were selected via random sampling and the effect of various physical parameters was seen on diabetic peripheral neuropathy. All the individuals were interviewed using a structured proforma after taking informed consent. A detailed clinical history was taken, complaints of the patients like polyuria, polydipsia, polyphagia, tingling sensation, burning sensation, pain in feet were noted. The duration of diabetes and age of onset of diabetes were noted. A thorough clinical examination was done. 
In general examination blood pressure, body weight and height was particularly noted. In systematic examination particular attention was paid to central nervous system, especially sensory system in form of touch, pain, temperature, vibration sense and position sense. Diagnosis of peripheral neuropathy was made on the basis of history, clinical examination, vibration perception with the help of biothesiometer.

The diagnosis of diabetes was made on the basis of WHO criteria as given below:

1. A random plasma glucose of $>200 \mathrm{mg} / \mathrm{dL}(11.1 \mathrm{mmoI} / \mathrm{L})$, associated with symptoms of hyperglycaemia (polyuria polydipsia, unexplained weight loss).

2. A fasting plasma glucose of $>126 \mathrm{mg} / \mathrm{dL}(7.0 \mathrm{mmol} / \mathrm{L})$.

3. A 2-hour glucose of $>200 \mathrm{mg} / \mathrm{dL}(11.1 \mathrm{mmol} / \mathrm{L})$ after a 75 $\mathrm{g}$ glucose load in the OGTT.

\section{Inclusion Criteria}

All the cases having fasting and post prandial glucose level higher than the above mentioned criteria of diagnosis for diabetes mellitus type-2 were included.

\section{Exclusion Criteria}

1. All the cases having peripheral neuropathy, which etiology has other than diabetes like other metabolic neuropathy and drug induced peripheral neuropathy and disease in which the sensory system is involved.

2. Creatinine $>2 \mathrm{mg} / \mathrm{dL}$.

3. Specific neurology diseases (Multiple sclerosis, stroke etc.).

4. Other causes of neuropathy ( $\mathrm{B}_{12}$ deficiency, alcoholism etc.).

5. Loss of dorsalis pedis pulses.

\section{STATISTICAL ANALYSIS}

Was done with the help of following formulae

1. Mean $=\sum x / n$
3. $\begin{aligned} & \mathrm{SD}=\sum x y / \sqrt{ } \sum\left(\sum x^{2} * \sum y^{2}\right) \\ & \mathrm{x}=\mathrm{X}-\mathrm{X}_{\text {mean }} \\ & \mathrm{y}=\mathrm{Y}-\mathrm{Y}_{\text {mean }} / \mathrm{n} \\ & \mathrm{SD}=\text { Standard Deviation, } \\ & \mathrm{r}=\text { Correlation coefficient } \\ & \mathrm{n}=\text { Total No. of Patients }\end{aligned}$

P-value estimated from the Correlation Coefficient Table with the help of degree of freedom. (Degree of freedom $=n-2$ ) Multiple regression - correlation was done using peripheral neuropathy as dependent variable and age, duration of disease, blood pressure and body mass index as independent variables.

\section{RESULTS}

A total of 102 patients of diabetes mellitus type 2 were enrolled with 53 females and 49 males. Out of 102 patients, 62 were suffering from peripheral neuropathy, i.e. vibratory perception threshold having $<20$ volts.

\begin{tabular}{|c|c|c|}
\hline $\begin{array}{c}\text { Age Group } \\
\text { (yrs.) }\end{array}$ & $\begin{array}{c}\text { No. of Patients } \\
\text { (n=102) }\end{array}$ & Percentage \\
\hline $30-44$ & 13 & 12.75 \\
\hline $45-59$ & 30 & 29.41 \\
\hline $60-74$ & 50 & 49.01 \\
\hline $75-89$ & 9 & 8.82 \\
\hline Gender & $\begin{array}{c}\text { No. of Patients } \\
\text { (n=102) }\end{array}$ & Percentage \\
\hline Male & 49 & 48.04 \\
\hline Female & 53 & 51.96 \\
\hline \multicolumn{2}{|c|}{$\begin{array}{r}\text { Table 1: Age and gender wise } \\
\text { distribution of diabetes patients }\end{array}$} \\
\hline
\end{tabular}

The youngest patient was 32 years of age and oldest was aged 80 years. Majority (49.01\%) belonged to $60-74$ years of age. The female:male ratio 1.08:1. (Table 1 ).

\begin{tabular}{|c|c|c|c|}
\hline Variable & $\begin{array}{c}\text { Diabetes } \\
\text { patients } \\
\text { with } \\
\text { neuropathy }\end{array}$ & r-value & p-value \\
\hline Age (Years) & $56 \pm 11.74$ & 0.285 & $<0.05$ \\
\hline $\begin{array}{c}\text { Duration of } \\
\text { disease (Years) }\end{array}$ & $10.00 \pm 5.31$ & 0.287 & $<0.05$ \\
\hline $\begin{array}{c}\text { Systolic blood } \\
\text { pressure } \\
\text { (mmHg) }\end{array}$ & $149 \pm 23.45$ & 0.04 & $>0.10$ \\
\hline $\begin{array}{c}\text { Diastolic blood } \\
\text { pressure } \\
\text { (mmHg) }\end{array}$ & $85 \pm 13.08$ & 0.208 & $>0.10$ \\
\hline BMI (Kg/m ${ }^{2}$ ) & $25 \pm 5.80$ & 0.233 & $>0.05$ \\
\hline \multicolumn{2}{|c|}{ Table 2: Factors associated with } \\
\hline diabetics having peripheral neuropathy \\
\hline
\end{tabular}

A significant positive correlation with age and duration of disease among the diabetics with neuropathy was found. (Table 2).

\begin{tabular}{|c|c|c|c|}
\hline Variable & $\begin{array}{c}\text { Patients } \\
\text { without } \\
\text { neuropathy }\end{array}$ & $\begin{array}{c}\text { r- } \\
\text { value }\end{array}$ & $\begin{array}{c}\text { p- } \\
\text { value }\end{array}$ \\
\hline Age (Years) & $62 \pm 10.37$ & 0.010 & $<0.10$ \\
\hline $\begin{array}{c}\text { Duration of } \\
\text { disease }\end{array}$ & $6.00 \pm 2.48$ & 0.029 & $>0.10$ \\
\hline $\begin{array}{c}\text { Systolic blood } \\
\text { pressure (mmHg) }\end{array}$ & $128 \pm 23.50$ & 0.160 & $>0.10$ \\
\hline $\begin{array}{c}\text { Diastolic blood } \\
\text { pressure (mmHg) }\end{array}$ & $80 \pm 11.68$ & 0.145 & $>0.10$ \\
\hline BMI & $24 \pm 3.70$ & 0.167 & $>0.10$ \\
\hline
\end{tabular}

An insignificant correlation with systolic and diastolic blood pressure and body mass index among patients with diabetes mellitus without neuropathy was observed (Table 3).

\section{DISCUSSION}

In this study, the prevalence of diabetic peripheral neuropathy was found to be $60.7 \%$. Similar prevalence $(60 \%)$ was found by Boru UT et al. in 2004 in Turkey. ${ }^{6}$ 
Lower prevalence (29.2\%) has been reported in a recent North Indian study. ${ }^{7}$ This could be attributed to different types of diabetes (e.g. type 1 and type 2 diabetes), sample selection and different diagnostic criteria used. Out of 62 patients of diabetic peripheral neuropathy, 53\% (33) were females and $47 \%$ (29) were males. Beghi E et al. (1997). ${ }^{8}$ also reported that diabetic polyneuropathy was more common among females in Italy. On the contrary, male preponderance was reported by Adgaonkar et al. (2014). ${ }^{9}$ in their Aurangabad study.

In this study, the majority of the patients belonged to 6074 years of age group. Flynn MD et al. (1995). ${ }^{10}$ found that age related prevalence of diabetic neuropathy peaked at age 40-49 years, which further increased with the increase in age. Maximum incidence was recorded in age group 51 to 60 years $(90.9 \%)$ in the Aurangabad study. ${ }^{9}$ In our study age of onset was significantly associated with peripheral neuropathy. Similar observations have been reported by Alder AI et al. (1997). ${ }^{11}$ and Cohen JA et al. (1998). ${ }^{12}$

In this study, duration of disease was significant risk factor for development of diabetic neuropathy. Our finding is supported by Rivillis IS et al. (2000). ${ }^{13}$ Ashok S et al. (2002). ${ }^{14}$ and Boru UT et al. (2004). ${ }^{6}$ and Bansal et al. ${ }^{7}$

In this study, the relationship between blood pressure (Both systolic and diastolic) and peripheral neuropathy was found to be statistically insignificant. Our finding is supported by Booya F et al. (2005). ${ }^{15}$ and Tamer A et al. (2006). ${ }^{16}$ who found no correlation between blood pressure and peripheral neuropathy.

Our result is contradictory to the study done by Varqhese A et al. (2001). ${ }^{17}$ which reported significant correlation between diastolic blood pressure and peripheral neuropathy. In this study we found that body mass index has no correlation with diabetic peripheral neuropathy, but height and body weight are independently associated with diabetic peripheral neuropathy.

Similar finding has been reported by Robinson LR et al. (1992). ${ }^{18}$ who found no significant relation between diabetic peripheral neuropathy and body mass index. Tesfaye et al. (1996). ${ }^{19}$ reported a positive correlation between height and diabetic peripheral neuropathy. Cohen JA et al. (1998). ${ }^{12}$ described body weight as an independent risk factor for diabetic peripheral neuropathy.

\section{CONCLUSION}

Prevalence of diabetic neuropathy in this north Indian study was high $60.7 \%$. A significant correlation with age and duration of disease was found. Early detection and treatment can be useful in preventing the progression of neuropathy among diabetics.

\section{REFERENCES}

1. Boulton AJ, Gries FA, Jervell JA. Guidelines for the diagnosis and outpatient management of diabetic peripheral neuropathy. Diabet Med 1998;24:55-65.

2. Sumner CJ, Sheth S, Griffin JW, et al. The spectrum of neuropathy in diabetes and impaired glucose tolerance. Neurology 2003;60:108-111.

3. Candrilli SD, Davis KL, Kan HJ, et al. Prevalence and the associated burden of illness of symptoms of diabetic peripheral neuropathy and diabetic retinopathy. J Diabetes Complications 2007;21:306-314.
4. Herman WH, Kennedy L. Underdiagnosis of peripheral neuropathy in type 2 diabetes. Diabetes Care 2005; 28:1480-1481.

5. Peripheral Neuropathy and Diabetes. Available from http://www.drstevenjdolgoff.com/diabetic_peripheral_ne uropathy_described_by_dr_steven_j_dolgoff.html

6. Boru UT, Alp R, Sargin H, et al. Prevalence of peripheral neuropathy in type 2 diabetic patients attending a diabetes center in Turkey. Endocr J 2004 Dec;51(6):563-7.

7. Bansal D, Gudala K, Muthyala H, et al. Prevalence and risk factors of development of peripheral diabetic neuropathy in type 2 diabetes mellitus in a tertiary care setting. J Diabetes Invest 2014;5:714-721.

8. Beghi E, Monticelli ML. Diabetic polyneuropathy in the elderly. Prevalence and risk factors in two geographic areas of Italy. Italian General Practitioner Study Group (IGPSG). Acta Neurol Scand 1997 Oct;96(4):223-8.

9. Adgaonkar AA, Dawange AA, Adgaonkar SA, et al. Clinical Profile of Peripheral Neuropathy in Diabetes Mellitus by Nerve Conduction Study. Sch J App Med Sci 2014;2(6A): 1973-1977.

10. Flynn MD, O'Brien IA, Corrall RJ. The prevalence of autonomic and peripheral neuropathy in insulin-treated diabetic subjects. Diabetes Med 1995 Apr;12(4):310-3.

11. Adler AI, Boyko EJ, Ahroni JH, et al. Risk factors for diabetic peripheral sensory neuropathy. Diabetes Care 1997;20(7):1162-7.

12. Cohen JA, Jeffers BW, Faldut D, et al. Risks for sensorimotor peripheral neuropathy and autonomic neuropathy in noninsulin-dependent diabetes mellitus (NIDDM). Muscle Nerve 1998;21(1):72-80.

13. Rivilis IS, Man'kovskii BN. Prevalence and risk factors for the development of diabetic neuropathy. Lik Sprava 2000 Oct-Dec;(7-8):69-71.

14. Ashok S, Ramu M, Deepa R, et al. Prevalence of neuropathy in type- 2 diabetic patients attending a diabetes center in South India. J Assoc Physicians India 2002 Apr;50:546-50.

15. Booya F, Bandarian F, Larijani B, et al. Potential risk factors for diabetic neuropathy: a case control study. BMC Neurol 2005;5:24.

16. Tamer A, Yildiz N, Kanat M, et al. The prevalence of neuropathy and relationship with risk factors in diabetic patients: a single-centre experience. Med Princ Pract 2006;15:190-194.

17. Varghese A, Deepa R, Rema $M$, et al. Prevalence of microalbuminuria in type 2 diabetes mellitus at a diabetes centre in Southern India. Postgrad Med J 2001; 77:399402.

18. Robinson LR, Stolov WC, Rubner DE, et al. Height is an independent risk factor for neuropathy in diabetes men. Diabetes Res Clin Pract 1992 May;16(2):97-102.

19. Tesfaye S, Stevens LK, Stephenson JM, et al. The prevalence of diabetic peripheral neuropathy and its relation to glycaemic control and potential risk factors. The EURODIAB IDDM Complications Study. Diabetologia 1996 Nov;39(11):1377-84. 